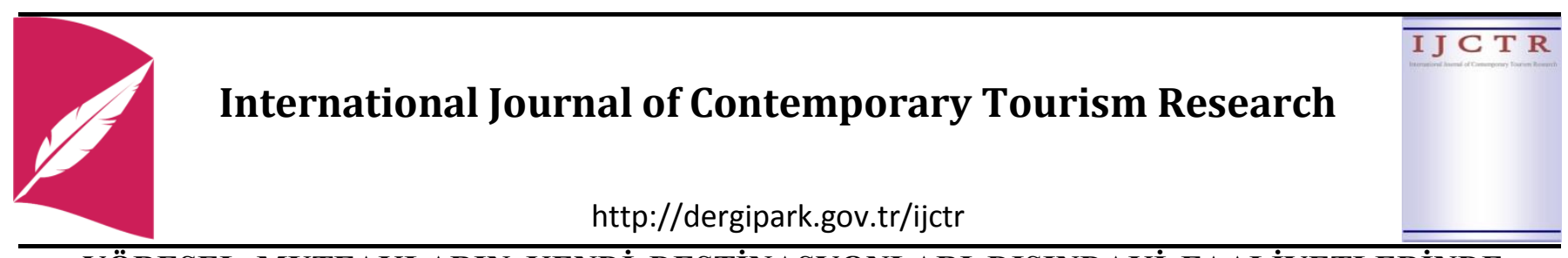

YÖRESEL MUTFAKLARIN KENDİ DESTINASYONLARI DIŞINDAKİ FAALIYYTLERİNDE KARŞILAŞILAN SORUNLAR ÜZERINE BIR ARAŞTIRMA ${ }^{1}$ Araştırma Makalesi

Evrim KARACA*, Mehmet SARIIŞIK **

ÖZET

Bu çalışmanın amacı Güneydoğu Anadolu mutfağının kendi coğrafi sınırları dışındaki faaliyetlerinde(satış, tanıtım vs.) yaşanan sorunları belirlemektir. Kendine has özellikleri olan bu mutfağın kültürel özelliklerinin yansıtılmasında ve ekonomik kazanca dönüştürülmesinde işletme yöneticilerinin karşılaştıkları sorunlar tespit edilerek öneriler sunulmuştur. Verilerin elde edilmesi için literatürden derlenen sorulardan oluşan mülakat formları İzmit’te faaliyet gösteren Güneydoğu Anadolu mutfağı (Mardin, Gaziantep, Şanlıurfa)ürünlerine odaklanmış5 restoran yöneticisine uygulanmıştır.

Yöneticilerden elde edilen verilere göre; Güneydoğu Anadolu mutfağının farklı bir destinasyonda üretim ve pazarlama konusundan daha önemli sorunlarının olduğu, bu sorunların başında ise; yöresel ürünlere ilişskin hammadde temini, nitelikli personel, yöre yemeklerinin tanıtımı, standartların noksanlığı ve damak tadına hitap edilememesi gelmektedir.

Anahtar Kelime: Türk Mutfağı, Güneydoğu Anadolu Mutfağı, Etnik Restoran

JEL Sinıflama Kodları: L83; L66

\title{
A RESEARCH ON THE PROBLEMS CONCERNED IN THEIR OPERATIONS OF THE REGIONAL KITCHENS APART FROM THEIR OWN DESTINATIONS SUMMARY \\ Research Article
}

The aim of this study is to identify the problems experienced in the activities of South-eastern Anatolia outside its geographical borders (sales, promotion etc.). Suggestions were presented by identifying the problems faced by business managers in reflecting the cultural characteristics of this cuisine with ethnic identity and transforming it into economic gain. In order to obtain the data, interview forms consisting of questions collected from the literature were applied to 5 restaurant managers focused on South-eastern Anatolian cuisine (Mardin, Gaziantep, Şanlıurfa) products operating in İzmit city center.

The data obtained from the administrators, shows that the South-eastern Anatolian cuisine has important problems in terms of production and marketing in a different destination. The main problems are the introduction of raw materials related to local products, presentation of local food, lack of standards and taste differences.

Keywords: Turkish Cuisine, South-eastern Anatolia Cuisine, Ethnic Restaurant

JEL Classification Code: L83; L66

\footnotetext{
${ }^{1}$ Bu çalışma “4. Uluslararası Türk Dünyası Turizm Sempozyumu”nda sözlü bildiri olarak sunulmuş ve sempozyum özet bildiriler kitabında yer almıştır.

* Öğr. Gör., Kırklareli Üniversitesi, Pınarhisar Meslek Yüksekokulu, evrimkaraca@klu.edu.tr, orcid.org/0000-0003-2520-5195

** Prof. Dr., Sakarya Üniversitesi, Turizm Fakültesi, msariisik@sakarya.edu.tr, orcid.org/0000-0002-0681-6137
}

"Karaca E. ve Sarışık M. (2018). Yöresel Mutfakların Kendi Destinasyonları Dışındaki Faaliyetlerinde Karşıllaşılan Sorunlar Üzerine Bir Araştırma, International Journal of Contemporary Tourism Research, Vol 2: No: 2, p1-10, doi: 10.30625/ijctr.437392"

Makale Gönderim Tarihi: 26.06.2018

Kabul Tarihi:14.07.2018 


\section{GİRIŞ}

İnsanların temel fizyolojik ihtiyaçlarından birisisi olan yemek yeme, son yüzyılda hıla gelişen yiyecek içecek endüstrisi ile birlikte dışarıdan karşılanan ve insanların boş zamanlarını değerlendirme yoluna gittikleri bir faaliyet haline gelmiştir. İnsanlar artık, sadece açlıklarını gidermek için değil farklı tatları deneyimlemek, gittikleri yerin atmosferinden, manzarasından ve farklı diğer koşullarından doyum sağlamak için dışarıda yemek yemeyi tercih etmektedirler. Aynı zamanda dışarıda yemek yeme turizm davranışı içerisinde yer alan bir davranıştır. Turistler gittikleri yerlerde, o yöreye ait yemekleri tüketerek yeni tatlar keşfetmek istemektedirler (Birdir ve Akgöl, 2015, s. 57-58).Turistlerin bu beklentilerine yanit vermede yöresel yemekler önemli bir firsattır. $\mathrm{Bu}$ açıdan bakıldığında gastronomi faaliyetleri bir bölgeyi ziyaret eden turistlerin en çok edinmek istedikleri turistik deneyimlerinin başında gelmektedir (Selwood,2003, s.179).

Dışarıda yemek yeme, ev dışında yiyecek ve içeceklerin tüketimini kapsayan bir kavramdır. Ticari anlamda dıșarıda yemek yeme, ev dıșında bir işletme tarafından üretilen ve sunulan yiyecek ve içeceklerin belirli bir ücret karşılığında tüketilmesini ifade eder. Bu durum yiyecek içecek işletmelerinin ürettiği ürünlerin çıkış noktasını oluşturduğu gibi varlık nedenlerinin de başında gelir (Özdemir,2010, s.218).

Geçmişten günümüze dünyadaki ticari anlamda ilk yeme içme kurumlarının 15. yüzyılda İngiltere' de yolculara yiyecek içecek hizmeti ile ortaya çıktıkları görülmektedir. 18. yüzyılın sonlarına doğru ticari faaliyetlerdeki artış, gıda endüstrisine de yansımış ve bu doğrultuda kafe, restoran, otel ve pansiyon sayılarında önemli artışlar olmuştur. 19. yüzyıla gelindiğinde otellerde yemek hizmeti verilmeye başlanmış, ancak bu hizmet oda servisi olarak sınırlı kalmıştır. 20. yüzyılda ise dışarıda yemek yeme faaliyeti, eğlence ve zevk amaçlı yapılmış ve sosyal yaşam tarzının bir parçası haline gelmiştir. En önemlisi, insanların seyahatleri esnasında dişarıdan yemek yemeleri ve bunu seyahatlerinin önemli bir parçası olarak görmeleri, ticari yemek kuruluşları için büyük bir firsat sağlamıştır (Shahrim,2006, s.16). Türkiye'de ise ticari anlamda restoranların açılması II. Meşrutiyet döneminde günlük yaşama girdiği konusunda genel bir düşünce bulunmaktadır (Doğdubay, 2000, s.34-35).

Geçmişten günümüze çeşitli aşamalarda geçen mutfak kültürleri kimi zaman bir diğerinden etkilenerek kaybolmaya kimi zaman ise etkisini hissettirerek ayakta kalmaya devam etmiştir. Bugün pek çok insan özelliği olan bir işletmeden ürün alma yoluna gitmektedir. $\mathrm{Bu}$ aynı zamanda yöresel yani etnik restoran işletmelerinde artmasına zemin hazırlamaktadır. Yöresel yemekler sunan ticari işletmelerinin pazarda çeşitli avantajları bulunmaktadır. Bu avantajlar şu şekilde siralanabilir (Smith ve Hall, 2003, s.249):

- Restoranlar genelde yaptıkları yemeklerin kullanımında gerekli olan yerel ürünleri rahatlıkla bulabilecek ve satın alabilecek yerleri seçerler.

- Yöresel restoranlar menüleri s1k sık değiştirir ve bu nedenle özel kullanımı olan ürünleri veya mevsimlik ürünleri bulmakta sıkıntı yaşamazlar.

- Restoranların depolama kapasiteleri daha düşük olduğu için ürün taleplerini yerel tedarikçilerden temin ederler.

- Yöresel restoranlar, servis personelinin menüdeki yöresel yemek hakkındaki bilgisi ve buna bağlı teşvikleriyle müşterinin yöresel yemeği tercih etmesi daha kolaydır.

- Yöresel restoran müşterileri, tatmin edici yöresel menü öğeleri için daha fazla ödeme yapmakta sorun çıkarmazlar.

- Restoranlar yerel olarak yetiştirilen ürünlerini menülerinde kendi yerel tedarikçilerinin isimlerini anlatarak vurgularsa marka bilinirliğini artırarak, pazarda işletmelerinin takip edilmesini sağlayabilirler

Dışarıda yemek yeme ticari bağlamda ele alındığında, turistlerin yeme içme hizmeti sunan işletmeyi tercihlerinde farklı unsurla Bulunmaktadır. Yöresel yemekler sunan işletmelerin tercih edilmesinde restoranın bulunduğu yer ve mimari tasarımı, gastronomik ürünlerin ticareti yapılan bölgenin ambiyansını oluşturması açısından önemlidir (Soriano, 2002, s.1055-1058). 
Türkiye, mutfak kültürü açısından oldukça zengin ve köklü bir geçmişe sahiptir (Arl1, 1982,s. 122; Talas, 2005,s. 276; Samanc1, 2008, s.24). Bunda en önemli etkiler, içinde bulunduğu coğrafi konum, köklü iki imparatorluğa ev sahibi olmanın getirmiş olduğu yiyecek içecek kültür zenginliğidir. Türkiye'de yerel mutfaklar kendilerine özgün etkileri içinde barındırarak, çok yönlü çeşitliliğe sahiptir (Çevik, 1997).Türk mutfağının çok çeşitli yöresel mutfaklara sahip olması aynı zamanda ülkenin mutfak zenginliğini de göstermektedir. $\mathrm{Bu}$ özelliklerinden dolayı da Çin ve Fransız mutfaklarıyla beraber, dünyanın ilk üç mutfağından birisi olarak ifade edilmektedir (Ertaş ve Gezmen, 2013). Türk mutfağı, zengin yemek çeşitliliği ve tatları açısından diğer ülkelerin mutfaklarından farklı1ık göstermektedir (Sezer, 2006,s.17; Tezcan, 2008, s.86).

Türkiye'nin sahip olduğu zengin mutfak kültürü, önemli bir gastronomik değer oluşturmaktadır. Türkiye'nin bu değerlerine sahip çıkması ve bunların gelecek nesillere de aktarılması kültürel kimlik kadar turizm açısından da önemli bir konudur. Özgüneş ve Bozok (2017) Bodrum'un yöresel mutfağına ilişkin yaptıkları çalışmalarında, yöresel mutfakların turizm çeşitliliği açısından önemli bir araç olarak kullanılabileceğini belirterek, burada yemeğin tadının ve özgünlüğüün korunmasında pişirme ve servis şekli başta olmak üzere pek çok unsurun etkili olduğunu açıklamışlardır.

Türkiye'nin her bölgesinin kendine has özellikleri bulunan mutfağa ve yöresel yemekleri bulunmaktadır. Özellikle "Güneydoğu Anadolu bölgesini 'Bereketli Hilal' denilen coğrafyada yer alması ve çeşitli uygarlıklara ev sahipliği yapması nedeniyle Türkiye'nin mutfak kültürünün çeşitlilik kazandığ1 en önemli bölgelerden birisi" durumundadır(Aksoy ve Sezgi, 2015,s.79). Ancak zengin bir mutfak kültürüne sahip olan Güneydoğu Anadolu mutfağının hak ettiği yerde olmadığ 1 söylenebilir. Güneydoğu Anadolu mutfağı başta tanıtım eksikliği olmak üzere, farklı nedenlerle, her zaman kendi coğrafyalarındaki başarıyı yakalayamadıkları dikkat çekmektedir. Bu durum Türkiye'de yöresel mutfak üzerine çalışan işletmelerin temel sorunları arasındadır. Nitekim Erdek (2011) İstanbul bölgesinde faaliyet gösteren yiyecek içecek işletmeler üzerinde gerçekleştirdiği araştırmasında; yöresel mutfağ 1 pazarlama faaliyetlerinde kullanan yiyecek içecek işletmelerinin sayıca yetersiz kaldığını ve yöresel Türk mutfağının tanıtımı ve geliştirilmesi konusunda önemli eksikliklerinin olduğunu belirlemiştir.

$\mathrm{Bu}$ çalışmada; Güneydoğu Anadolu mutfağ üzerine İzmit'te çalışan işletmelerin karşılaştıkları sorunları tespit etmek ve çözüm önerileri geliştirmek amaçlanmıştır. $\mathrm{Bu}$ doğrultuda Güneydoğu Anadolu mutfağı menüsüne sahip işletme yöneticilerinin görüşleri alınarak değerlendirmeler yapılmıştır.

\section{YÖNTEM}

Nitel araştırma modelinin kullanıldığı çalışmada Güneydoğu Anadolu mutfağının yaşadığı sorunların belirlenmesi ve ilgili çözüm önerileri geliştirilebilmesi için betimsel tarama modelinden yararlanılmıştır. Tarama modelleri, geçmişte veya şu anda var olan bir durumu var olduğu haliyle betimleyen bir model olarak açıklanmaktadır (Karasar, 2014, s.77).

"Nitel araştırmada, geleneksel olarak üç temel bilgi toplama şekli bulunmaktadır. Bunlar mülakat, gözlem, doküman ve eserlerin incelenmesidir" (Merriam, 2013). $\mathrm{Bu}$ araştırmada veriler yapılandırılmış mülakat tekniğiyle toplanmıştır. Nitel araştırmada kullanılan mülakat tekniğinin belirleyici özelliği, görüşülen kişilerin bakış açılarını ortaya çıkarma olmaktadır. Bu nedenle görüşme yapılan yöneticilerin anlam dünyalarını, duygu ve düşüncelerini anlamak, nicel görüssmelerden farklı olarak yüzeysel değil daha derinlemesine bilgi edinmek esas alınmıştır (Karasar, 2014).

Araştırmanın evrenini Kocaeli il sınırları içerisinde yer alan ve önemli etnik mutfaklar arasında gösterilen Güneydoğu Anadolu orijinli menüye sahip birinci sınıf işletmelerden seçilmiştir. Toplam yirmi beş işletme sahibi veya yöneticilerine ulaşılarak görüşme talep edilmiş ve bunlardan beşi olumlu yanıt vermiştir. Haziran 2018'de katılımcılarla yüz yüze görüşmeler gerçekleştirilerek kayıt altına alınmıştır. Araştırmada yapılandırılmış mülakat tekniği üzerinden ilgili mutfağa sahip işletmelerin karşılaştıkları sorunlara ilişkin on iki soru yöneltilmiş ve elde edilen yanıtlar içerik analizine tabi tutulmuştur. Görüşmeler yazılı olarak kayıt altına alınmış ve değerlendirilmişstir. 


\section{BULGULAR}

Araştırmaya katılan işletmecilere öncelikle "Güneydoğu mutfağın yöresel yemeklerin satıyorsunuz, bu süreçte yaşadığınız en önemli sorunlar nelerdir, anlatır misiniz?" sorusu yöneltilmiştir. İşletmecilerden aşağıdaki yanıtlar alınmıştır.

Yanıt 1: Önemli sorunlardan ilki bölgeler arasındaki damak tadı farkıdır. İzmit bütün bölgelerden birçok bireyi bir arada yaşadığ kent ve dolayısıyla farklı kültürler ve kimliklerin bir mozaiği söz konusudur. Gaziantep mutfağı et kültürü, baharat kültürü ve soğan sarımsağ1 yemeklerinde lezzet arttırmak amaciyla kullanilan faktörlerdir. Bunlar bazı müşterileri rahatsız eder dolayısıyla bu noktada damak tadı fark1 ortaya çıkar. Et tüketmeyenler, et tüketen fakat baharat tüketmeyenler, et tüketen fakat yağsız et tüketenler için bir lezzet veya damak tad1 standardını yakalayabilmek bu tarz yerler de oldukça zordur.

Yanit 2: En önemli sorun nitelikli personel sorunudur. Yiyecek içecek sektörü emek-yoğun bir özelliğe sahiptir. Bu açıdan nitelikli insan gücü önemli bir unsur olarak ortaya çıkar. Fakat eğitimli ve nitelikli insan gücü bulmakta zordur. Bunun yanında iş görenlerde süreklilik sağlamak diğer sektörlere göre daha zordur. Ek olarak iş gören devir hızı da diğer sektörlere göre daha yüksektir. Ağırlama sektörü dinamik bir sektör olduğundan ve uzun / yoğun çalışma saatlerinden ötürü çalışanların önemli bir bölümü gençtir. Deneyimi olmayan çalışanlar, bekârlar, gençler işten daha kolay ayrılma kararı verebilmekte ve devir hızını arttırmaktadır. Kilit noktadaki iş görenlerin işten ayrılması da işletmeyi zora sokmaktadır.

Diğer bir mücadelemiz, sektör içerisinde yer alan seyyar satıcılardır. Biz vergimizi verip, kira ödeyip, istihdam sağlarken; diğer tarafta haksız rekabete yol açan seyyar satıcılar var. Hem hijyenik olmayan koşullarda üretim yapıyorlar, hem de sektör içerisinde haksız rekabete yol açıyorlar. Bununla da mücadelemizi sürdürüyoruz.

Yanıt 3:Bölgeye gelen insanlar yemeklerimizi lezzetli bulmakla beraber aynı zamanda kalorisi yüksek olarak bulmaktadırlar. Dolayısı ile en fazla 2 veya 3 gün bu yemekler tercih konusu oluyor. Ondan sora ki süreçlerde müşteriler başka mutfaklara yöneliyorlar. Bu da bizim için sorun teşkil etmektedir.

Yanit 4: En önemli sorunlardan ilki kebaplarda kullanılan kuyruk yağı, yöresel baharatlar ve ürünleri bulamamakta yaşadığımız sıkıntılardır. Güneydoğu Anadolu'dan bu ürünleri getirtmek zaman ve nakliye ücreti açısından maliyetleri yükseltmektedir. Çünkü yöresel bir mutfağı olan bir işletme her ne kadar istihdam, ekonomik katk1, tanıtım sosyal fayda sağlasa da işletmenin temel amac1 yüksek karlılığı sağlamak ve devamlılığını sürdürmektir.

Yanıt 5:Ben 9 yıldır Gaziantep'te çalıştım. Bilindiği üzere bölgenin en kapsaml, en geniş ve en zengin mutfağına sahiptir. En büyük sıkıntının yemeklerin bir reçetesinin olmaması ve herkesin evinde ayrı bir reçete ile pişirmesidir. Karşılaştığımız olaylar genellikle standardın olmaması ve herkesin kendine göre ayn yemekte farklı tatlar yaratmasıdır. Satılan yemekler ile ilgili bir sorun yok çünkü misafirler yerli ve yabanc1 turistlerden oluşuyor. Gaziantep'e gelmişken yöresel yemekleri tatmak istiyorlar. Tabi ki büyük bir sıkıntı yabancı turist için her yerde aynı standartlarda yemek yiyemiyorlar. En önemli sorunlardan birisi ise işletmelerin ticari kaygısı ile maliyetleri geri çekebilmek adına yaptıkları satın almalardan dolayı kullanılan ürünlerin kalitesinin düşük olmasıdır. Bu durum yemeğin kalitesini ve özünü kaybettirmektedir.

Araştırmaya katılan işletmecilere "Yaşanan sorunlar, güneydoğu mutfă̆ına mı özel, yoksa diğer yiyecek işletmelerinde benzer sorunlar yaşanıyor mu?"

sorusu yöneltilmiştir. İşletmecilerden aşağıdaki yanıtlar alınmıştır.

Yanıt 1: Bence İzmit'te diğer bölge yöresel mutfaklarına sahip olan tüm işletmelerde aynı sorunlar yaşanmaktadır. Çünkü bir Gaziantepli olarak bana nasıl Ege mutfağının bol otlu ve etsiz zeytinyağlı yemekleri benim damak tadıma uzak geliyorsa emin olun klasik bir Egeli içinde Gaziantep mutfağı da uzak kalmaktadır. Bu yüzden bu sorun bölgeler arasinda mevcut diye düşünmekteyim.

Yanit 2: Nitelikli personel bulma, hijyen ve seyyar satıcılarla mücadelenin diğer yiyecek-içecek işletmelerinin de ortak problemi olduğunu gözlemliyoruz. Özellikle nitelikli iş gücü gittikçe 
artan bir sorun olarak karşımıza çıkıyor. Öyle ki bu sorun yiyecek içecek işletmelerinin yeni şube açma isteğinin önünü kesecek boyuttadır.

Yanıt 3: Bir kısmı işletme kaynaklı problemler olarak görülebilir. Çünkü bazı işletmeler pazarlama konusunda eksiklikler yaşamaktadırlar. Ürünü sağlıklı bir şekilde pazarlamamak bölgede ki en büyük işletme sorunlarından bir tanesidir.

Yanıt 4: $\mathrm{Bu}$ sorunların tamamı Güneydoğu mutfağına yönelik olsa da benzer sorunlar diğer mutfaklar içinde geçerli olabilir. Zengin bir mutfak kültürüne sahip olan Güneydoğu Anadolu mutfağ1 medeniyetlerin buluştuğu topraklar olduğundan mutfağa da bu yansımış ve yeme içme sektörü çok çeşitlilik göstermekte ve bunu büyük şehirlerde yaşatmak bu damak tatlarını yöre dışı müşterilere sunmak ve sevdirebilmek bir meziyet olsa gerek. Ürünleri başka iller de özellikle büyük şehirlerde bulmak lojistiğini sağlamak başka sorun. Diğer bölgelere baktığınızda Güneydoğu Anadolu mutfağında kullanıldığı kadar çeşitli baharat yoktur. Ürünler her yerde bulunabilecek türdendir.

Yanıt 5: Sadece yöresel ve yerel mutfağımız için değil ülke olarak Türk Mutfağı olarak genel sorunumuz yemeklerde standardın olmayışıdır.

Araştırmaya katılan işletmecilere " $\mathrm{Bu}$ sorunların çözümüne yönelik neler yapıyorsunuz?” sorusu yöneltilmiştir. İşletmecilerden aşağıdaki yanıtlar alınmıştır.

Yanıt 1: Özellikle gurup olarak gelen müşteriler arasında damak tadımıza uzak olan müşteriler için ayrı bir menü seçeneklerinden yani alternatifeler sunuyoruz ve memnuniyetlerini sağliyoruz.

Yanıt 2:Yüzde yüz iş garantili eğitim projelerini gerçekleştirmek üzere çalışmalara başladık. 15-40 yaş arası, yiyecek içecek sektörünü benimseyen ve bu sektörde çalışmak isteyen kişiler bu haktan yararlanabilecekler. Bu konuda da talebin ne yazık ki yüzde iki oranın da olduğunu görüyoruz.

Yanit 3: AB Projeleri, SODES, UNDP destekli projelerle bilinçlendirme eğitimleri sağlanıyor.

Yanıt 4: Örneğin 1. Sorun kuyruk yağı sorunu olup bu yağı kebaplarımızda azalttık. 2. Sorun baharatlar ve yöresel malzeme bunu da kendi yöremizle yani Güneydoğuda bağlantılar kurarak temin ediyoruz 3. Bulamadığımız ev ürünlerini de örneğin kuru patlıcan domates isot gibi yöredeki ev hanımlarıyla görüşüyoruz bizim istediğimiz standartlarda hazırlıyorlar. İstediğimiz yöresel ürünü bu şekilde temin etme yoluna gidiyoruz.

Yanıt 5: Biz kendi yöremizde bu sorun üzerine bir kurul toplayarak yemek üzerine standartlaşması için bir çalışma yaptık. Bunun ülke geneline yayılıp belirli bir standarda bağlanması gerekiyor.

Araştırmaya katılan işletmecilere "Güneydoğu mutfağın tanitılmasina yönelik sizce neler yapılmalıdır?" sorusu yöneltilmiştir. İşletmecilerden aşağıdaki yanıtlar alınmıştır.

Yanit 1:Öncelikle Belediye ve diğer ilgili kurum desteği ile yöre lezzet tanıtım günleri yapılabilir. Bazı alışveriş merkezlerinde stant açarak belli günlerde tadım yaptırılabilir. Gastronomi Fuarlarının sadece bir iki büyük kentinde sınırlı kalmamalı artık her ilde düzenlenebilir.

\section{Yantt 2:}

- Güneydoğu Anadolu mutfağına turistlerin ilgisi oldukça yoğun... "Güneydoğu Anadolu Gurme Turları" düzenlenmelidir.

- Yerel konaklama hizmetlerini tercih eden turistler, yöresel yemek kültürü ile daha yakından tanışma imkânı buluyorlar. Diğer konaklama hizmetlerinden birini tercih edenler için ise, yiyecek-içecek departmanlarında yöresel mutfağın öne çıkarılması gereklidir.

- Yemek yarışmaları düzenlenebilir.

- Yurt içi ve yurt dışı festivaller, basının da dahil olduğu biçimde organizasyonu gerçekleştirilerek her yıl düzenlenen geleneksel bir anlayış çerçevesine dönüştürülmelidir.

- Belediyelerin Büyükşehir'e dahil edilmesi ile destek verebileceği çevre beldelerin sayısı çoğalmış olup, bu doğrultuda belediyelere büyük sorumluluk düşmektedir. Bu kapsamda kitap çalışmaları yapılabilir ve Güneydoğu Anadolu mutfağına ait reçetelerin sonraki nesillere yazılı olarak aktarılma şans1 doğabilir.

Yanit 3: Proje uygulanmalıdır (AB, UNDP, Kırsal Kalkınma Projeleri vb).

Yanıt 4:Yemek yarışmaları düzenlenebilir festivaller fuarlar yapılabilir. Örneğin tüm büyük şehirlerde bir hafta sürebilecek güney doğu yemekleri şenliği yapıla bilir o yörenin esnafları 
stant açıp satış yapar hem de yöreyi tanıtmış olur uluslar arası platformda da bu tür projeler hayata geçirilebilir.

Yanıt 5:Yapılacak işlemlerin başında olması gereken devletin bu işlere sahip çıkmasıdır. Yemek kültürü de bir mirastır. Bu kültürü devam ettirip yaşatmak ta bence çok önemlidir. Turizmden kazandığımız kadar gastronomi turizmini başlatıp neden bundan da kazanmayalım. Bence bunun üzerine profesyonel ekipler kurulup çalışması yapılmalıdır. Lansmanlar yapılmalı, fuarlar yapılmalı eğitime önem verilmeli. Devletin bunu teşvik etmesi gerekmektedir.

Araştırmaya katılan işletmecilere "Yaşanan sorunların çözüm ne yönelik neler yapılabilir, önerileniz nelerdir?" sorusu yöneltilmiştir. İşletmecilerden aşağıdaki yanıtlar alınmıştır.

Yanıt 1:Ulaşılabildiği kadar kitleye ulaşılmalı. Tabii bunlar için belli bir bütçe ayırmak gerekiyor fakat Farklı bir coğrafyada iseniz ve işletmeler arasında liste başı olabilmek ve uzun vadeli bir işletme olmak istiyorsanız tanıtımlarınızı iyi yapmanız gerekmektedir. Bazı giderleri de hesaplamanız ve bunlar için bütçe ayırmanız gerekmektedir. Başka türlü tutunamazsınız. Kendi bölgenizde olsaydınız da tanıtım için belli bir bütçeyi ayırmanız ve bunun için harcamanız gerekmektedir.

\section{Yanit 2:}

- Esnaf ve Sanatkârlar Odaları; İl Müdürlükleri, Vali, Belediye Başkanları, Bakanlar, Milletvekilleri gibi ilgili mercilerle görüşmeli ve Güneydoğu Anadolu mutfağının dünyaya tanıtılmasında hak ettiği değeri görmesine yönelik ortak çalışmalar yapılmalıdır.

- Esnaf ve sanatkârlar masası kurulmalı; esnaftan sorumlu vali yardımcısı atanarak yiyecek-içecek işletmelerinin sorunları en kısa yoldan yetkililere ulaştırılıp çözüm yolları aranmalıdir.

- Esnaf ve sanatkârlar oda başkanları yiyecek içecek işi ile uğraşan esnaf ile iç içe olup sorunları ilk ağızdan dinlemeli ve odalar birliğine / federasyona ve konfederasyonlara iletmelidir.

- Güneydoğu Anadolu mutfağı adına hizmet veren yiyecek içecek işletmeleri; festival, indirim, cazip kampanyalar, reklamlar aracılığ ile ilgiyi sürekli olarak üzerinde tutmalıdır.

Yanıt 3:İşletme sahipleri ve yöneticilerin branş eğitimleri ile donatılması yeterli olacaktır.

Yanıt 4: Güneydoğu mutfağının standartlarının oluşturulması lazım örneğin nerde bir kebap yerseniz hepsi bir birinden farklı bunu bir standart olmal1. Örneğin güney doğu mutfağı yapan tüm esnaf bir birlik kurmalı ve bu birlik adı altında hareket ederek projeler geliştirmeliler. AR-GE yapıp standartları oluşturmalı

Yanıt 5:Yemek kültürü de bir tarihtir. Bence yazılı kayıt altına alınmalı ve gelecek nesillere miras olarak aktarılmalıdır. Teşvikler sağlanmalıdır. Türk mutfağ1 reçetelendirilmelidir. Bugün dünya mutfaklarının bizden daha önde gözükmesinin ve olmasının sebebi bu çalışmaları yapmış olmalarıdır. Sunum çok önemlidir. Bizim kültürümüzdeki yemeklerin çoğunluğu kazan yemeği olduğu için buna önem verilmeli çünkü bu bir dezavantaj. Kendi öz kültürümüze ve kendi öz yemeklerimize sahip çıkıp bunları orijinal dokusunu bozmadan korumalı ve yaşatmalıyız.

Araştırmaya katılan işletmecilere "Yöresel mutfak olarak işletmenizde çalıştırdığınız personel de yöresel kuyafetler kullaniyor mu?" sorusu yöneltilmiştir. İşletmecilerden aşağıdaki yanıtlar alınmıştır.

Yanıt 1:Hayır kullanılmıyor. İşletmenin uygun bulduğu standart iş kiyafetleri personelin giyinmesi sağlanıyor. Aslında yöresel kıyafet giymeleri, özellikle servis kısmındaki personelin fakat bunları tedarik etmek her yönden zor, bunun başında maliyet olarak düşünüyoruz. İzmit Bölgesinde bunları tasarımı yapıp bir Tekstil firmas1 ile anlaşılması ile maliyetinizi arttırıyorsunuz çünkü ne yazık ki bir personeli uzun yıllar işletmenizde tutamıyorsunuz onun üzerine göre tasarlanmış iş kıyafetini de öyle standart düşünmeliyiz ki personel sirkülâsyonunda kıyafet sıkıntısını da düşünmemek gerekiyor. Biliyorsunuz ki her bir kalem için ayrı bir maliyet ayrılmalı ben bütçemi daha çok tanıtıma yatırmaktan yanayım.

Yanıt 2:Yüzde 1 ile 2 oranında yöresel kıyafetler ile hizmet sunulduğunu görüyoruz.

Yanit 3: Evet. 
Yanit 4: Evet ve kullanılmakta da yarar var sadece kıyafet değil yörenin dokusunu taşıyacak her şey müzikten tutun gelenek ve görenekler bile sergilenmelidir. benim işletmemde değil ama daha lokal çalışan yerlerde evet var.

Araştırmaya katılan işletmecilere "Yörenize ait sunum şekilleriniz var mi, varsa işletmenizde uygulaniyor mu?" sorusu yöneltilmiştir. İşletmecilerden aşağıdaki yanıtlar alınmıştır.

Yanıt 1: Evet her yöresel mutfağı başka bir ilde yaşatmaya çalışan yiyecek içecek işletmeleri gibi bizde de geleneksel yöntemlerimizle sunumlarımız mevcut ve müşteriye bu şekillerde sunmanın ayrıcalıklarını gösterme yöndeyiz. Aslında bakarsanız yöresel mutfağı başka bir bölgede tanıtmak için İşletmenin ilk giriş kapısından buradan çıkışına kadar Müşterinin İşletmemize attığ 1 her adımında, etrafına yani duvarlara varana dek kullanılan her bir objeye her bakışında, Gaziantep yöresini yansıtan temalar olmalı tabii.

Yanıt 2: Bunun için gerekli olan bilgi ve donanım, ne yazık ki hem personel açısından hem de gerekli olan servis malzemelerinin maliyeti açısından çok gerekli görülmüyor yatırımcılarca... Yemeğin lezzetine sunumundan daha çok önem verildiğini ve müşteri istekleri doğrultusunda damak zevkine diğer unsurlardan daha çok ağırlık verildiğini ifade ediyorlar.

\section{Yanıt 3: Evet.}

Yanıt 4: Evet var ve uyguluyoruz örneğin Mira'nın kendine has bir sunum şekli var bunun gibi birçok üründe de var kendine has sunum özeliği olan ürünler.

Yanıt 5: Evet var, sunum çok önemli. Sunum şekilleri geliştirilmelidir.

Araştırmaya katılan işletmecilere "Müş̧terinin yöresel mutfağınıza karşı ilgisi ne yönde?" sorusu yöneltilmiştir. İşletmecilerden aşağıdaki yanıtlar alınmıştır.

Yanit 1:Genelde müşteri memnun fakat ilk soruda ki yanıtımdaki gibi bazılarına damak tadı farklı gelmektedir. Ama genel olarak memnuniyet mesajlarını ya sözel ya da telefona gelen mesajlarla görebilmekteyiz. Müşterilerimizin memnuniyeti bizi mutlu etmektedir. Aslında eleştiriler de memnun etmekte çünkü kendimizi geliştirmemizi sağlamakta.
Yanıt 2: Oldukça yüksek bir ilgi ve talep gördügünü rahatlıkla söyleyebiliriz. Güneydoğu Anadolu mutfağının müşteri kitlesinin damak tadı diğer mutfaklara göre daha duyarlı... Fakat bu yoğun ilgi ile aynı doğrultuda işletmelerin gelişmediğini görüyoruz. Yani müşteri talebi ve beklentileri ile işletmelerin yenilik ve gelişim hızı aynı doğrultuda ilerlemiyor ne yazık ki... Güneydoğu Anadolu mutfağını yöneten işletmelerce "damak tadı" her şeyin üstünde geliyor ve bu konuda kendilerine yüksek özgüven duyuyorlar. $\mathrm{Bu}$ da gelişmenin önünü kesen bir unsur olarak karşımıza çıkıyor.

Yanıt 3:Olumlu yönde ilerleyiş var. Talep yoğunluğu mevcuttur.

Yanit 4: Severek ve beğenerek yiyorlar. Misafirlerimiz çoğunluğu yöresel yemek yemek istiyorlar. Tatbiki de bende yurt dışına çıktığım zaman oranın yöresel yemeklerinden yiyip tatmak ve o yörenin yemek kültürünü anlamak ve tanımak isterim.

Araştırmaya katılan işletmecilere "İşletmenize gelen müşteriler sadece kendi memleketinizden olan müssteri portföyü mü yoksa genel müşteriler $m i$ ?" sorusu yöneltilmiştir. İşletmecilerden aşağıdaki yanıtlar alınmıştır.

Yanıt 1:Hayır sadece Gaziantep yöresinden değil genel olarak müşterilerimiz gelmektedir. Pazar günleri özellikle sabah Gaziantepliler gelmekte çünkü yöresel sabah kahvaltısında yenen bazı lezzetlerimiz var sırf bunların lezzeti için gelmekteler. Bunlardan bir kaçı; Ciğer, Beyran ve Nohut dürümü gibi yörede sabah kahvaltılarında yenir ve bu lezzetleri bizde yemeğe gelen standart müşteri portföyümüz bulunmakta.

Yanıt 2: "Genel olarak" yüksek ilgi gördüğünü ve sadece o bölgenin müşterisine değil; hem yurt içindeki diğer bölgelerden gelen yurttaşlarımıza, hem de yurt dişından gelen turistlere hitap eden bir kültür olduğunu söyleyebiliriz Güneydoğu Anadolu mutfağının...

Yanıt 3:Türkiye geneli ve Avrupa ülkelerinden gelen bir portföyü var.

Yanit 4: Genel hata yabanc1 misafirlerimizde $r$ zaman zaman oluyor.

Yanıt 5:İl genelinden ve dişından Türk misafirler ve yabanc1 turistler 
Araştırmaya katılan işletmecilere "İ̧sletmenizde çalıştırdığınız mutfak personeli özelikle aşçılarınız memleketten mi?” sorusu yöneltilmiştir. İşletmecilerden aşağıdaki yanıtlar alınmıştır.

Yanit 1: Ustabaşının memleketten olmasi gerekmekte, çünkü o mutfağın kültürü ile harmanlanmış kişi bu lezzetleri koordine ederek müşteriye sunmamız ve istenen lezzeti tanıtmamız bu şekilde mümkün olabilmektedir.

Yanit 2: Yüzde doksan sekiz oranında memleketten gelen aşçılara teslim ediliyor mutfaklar... Böylesinin hem güven açısından, hem de hakkıyla lezzet sunulmasında gerekli olduğuna inanılıyor.

Yanit 3: Evet.

Yanıt 4: Kimisi memleketten kimisi buradan. Bu bölgeden olan personele uygulamalı eğitimler verilmektedir. Yöre mutfağı tanıtılmakta ve işbaşında eğitim uygulanmaktadır.

Yanit 5: Evet.

Araştırmaya katılan işletmecilere "Yöre yemeklerini bilen bir aşçıyla mı çalışıyorsunuz?" sorusu yöneltilmiştir. İşletmecilerden aşağıdaki yanıtlar alınmıştır.

Yanıt 1:Evet Ustabaş1 yanına bu yemekleri bilen ama Gaziantepli olmayan ustamızda bulunmakta.

Yanit 2: Evet.

Yanit 3:Evet.

Yanit 4: Evet.

Araştırmaya katılan işletmecilere "Aşçılarınızı bir eğitim verilip veya ögretim ile mi çalıştırıyorsunuz?" sorusu yöneltilmiştir. İşletmecilerden aşağıdaki yanıtlar alınmıştır.

Yanıt 1:Ustabaşı usta ve yanlarında bu yöreye yabancı bir aşçıya da işbaşında eğitim vererek veya işbaşında uygulamalı olarak eğitim vermekteyiz.

Yanit 2: Evet.

Yanit 3: Evet.

Yanit 4: Evet.

Yanit 5: Evet.

Araştırmaya katılan işletmecilere "İşletmenize gelen müssterilere memnuniyet anketi gibi bir uygulama kullaniyor musunuz?" sorusu yöneltilmiştir. İşletmecilerden aşağıdaki yanıtlar alınmıştır.

Yanıt 1:Hayır kayıtlı olarak bir memnuniyet anketi kullanmıyoruz. İşletme olarak bizler müşterinin yüz ifadeleri ve işletmemizden ayrılırken sözel olarak ifadelerini temel alıyoruz.

Yanit 2: Hayır, uygulanmiyor.

Yanit 3: Evet.

Yanit 4: Evet.

Yanıt 5: Tabii ki kendimizde ölçmemiz gerekiyor. Bir yerde her zaman övgü olmaz şikayette olmalı. Şikayet yoksa yanlış bir şeyler vardır.

\section{SONUÇ}

Güneydoğu Anadolu mutfağının ticari amaçlı değerlendirilmesinde yaşanan sorunları belirlemek ve ilgili çözüm önerileri geliştirmeye yönelik, Güneydoğu Anadolu mutfağına özgün İzmit merkezde faaliyet gösteren işletmecilerin görüşlerini değerlendirmek amaciyla gerçekleştirilen araştırmadan ortaya çıkan sonuçları şu şekilde özetlemek mümkündür.

Güneydoğu Anadolu mutfağının tanıtımı ve pazarlanmasında ciddi sorunlarla karşı karşıyadır. $\mathrm{Bu}$ sorunlar içsel veya dışsal kaynaklıdır. Bölgeler arasındaki lezzet farklılığı, özellikle yerli turistlerde karşılaşılan önemli bir sorundur. Bol etli, yağglı ve baharatlı yemekler, yöre dışındaki bazı insanların hoşuna giderken, diğerlerinin gitmemektedir. Diğer taraftan yemeklerin kalori değeri yüksektir. Üç öğün yörenin yemekleri tercih edilmeyip, özel günlerde daha çok tercih edilmektedir. Hemen hemen her ilde özellikle Antep ve Urfa mutfağ 1 üzerine çalışan işletmeler bulunmaktadır. Yemeklerin yapımında bir standart olmadığından dolayı, aynı mutfaklara dair aynı yemekler farklı lezzetlerde sunulmaktadır. $\mathrm{Bu}$ durum tüketicinin mutfağa karşı olan ilgisini azaltmaktadır. Diğer taraftan araştırma kapsamındaki Güneydoğu mutfağı üzerine çalışan işletmeler, yöresel ürünleri bulmakta ve temin etmekte güçlük yaşamaktadırlar. Sektörde diğer önemli bir sorun ise nitelikli personeldir. Eğitimli ve konusuna hâkim nitelikli personele sektörde ihtiyaç duyulmaktadır.

Güneydoğu Anadolu mutfağın yönelik hizmet veren işletmelerde yaşanan bu sorunlar, diğer 
bölgelere ait yöresel mutfaklarda da yaşandığ 1 işletmeci görüşlerinden ortaya çıkmıştır.

Bu sorunların giderilmesi için işletmeciler, damak tadı farklı olan tüketicilere yönelik alternatif menüler hazırlamakta olduklarını, nitelikli personel sorununu çözmek için yüzde yüz iş garantili eğitim projeleri düzenlediklerini, yemeklerdeki yă̆ oranını azalttıklarını ve kendi bölgelerinden üreticilerle iletişim kurarak, yöresel ürünleri temin etmeye çalıştıklarını belirtmişlerdir. Gaziantepli işletmeciler, mutfaklarındaki yemeklerin standardizasyonuna yönelik çalışmalar içerisinde olduklarını da ifade etmişlerdir.

Güneydoğu mutfağının tanıtılmasına yönelik işletmecilerin öne çıkan önerileri şunlardır:

- Yurtiçi ve yurtdişı organizasyonlarda, mutfağın başlıca yemekleri tanıtılmalıdır.

- Güneydoğu Anadolu'ya özel gurme turları düzenlenmelidir.

- Yemek yarışmaları festivaller düzenlenmelidir.

- AVM'lerde lezzet tanıtım günleri düzenlenmelidir.

- Yaşanan sorunlarına yönelik olarak yapılması gereken öneriler ise şunlardır:

- Hedef kitlelere ulaşmak için etkin tanıtımlar yapilmalı

- Esnaf ve Sanatkârlar Odaları; İl Müdürlükleri, Valilik ve belediyelerle işbirliği yapılarak ortak çalışmalar düzenlenmelidir.

- Güneydoğu Anadolu mutfağı adına hizmet veren yiyecek içecek işletmeleri; festival, indirim, cazip kampanyalar, reklamlar aracılığ ile ilgiyi sürekli olarak üzerinde tutmalıdır.

- Güneydoğu Anadolu mutfağında yer alan yemeklere dair standartlar oluşturulmalı ve her yerde aynı yöreye ait yemek yendiğinde aynı lezzette olması sağlanmalıdır.

Sonuç olarak; Güneydoğu Anadolu mutfağ 1 ticarileştirilme aşamasında İzmit'te bazı sorunlarla karşı karşıyadır. Bu ve bunun gibi sorunlarla karşı karşıya kalan işletmelerin bu araştırmada olduğu gibi karşılaştıkları sorunları belirlenmeleri gereklidir. Sonrasında ilgili kurum ve kuruluşlarla işbirliğine gidilerek sorunlar çözüme kavuşturulmaya çalışılmalıdır. Müşterilere yönelik memnuniyet anketleri mutlaka düzenlenmeli, memnuniyetsizliğin oluştuğu noktalara yönelik iyileştirici çalışmalar yapılmalıdır.

$\mathrm{Bu}$ araştırma İzmit'te Güneydoğu Anadolu mutfağına özel yemekler sunan beş işletmenin yöneticisinin görüşleri ile sınırlıdır. Araştırma verilerinden genel sonuçlara ulaşabilmek için, daha geniş örneklemler üzerinde araştırmanın benzerleri yapılabilir. Ayrıca, anket, gözlem gibi farklı veri toplama araçları ile yapılacak araştırmalarla daha detaylı sonuçlara ulaşılabilir.

\section{KAYNAKÇA}

Aksoy, M. Ve Sezgi, G. (2015). Gastronomi turizmi ve Güneydoğu Anadolu Bölgesi gastronomik unsurlar1. Journal of Tourism and Gastronomy Studies, 3 (3), 79-89

Arlı, M. (1982). Türk mutfağına genel bir bakış. Geleneksel Türk Mutfağı Sempozyumu Bildirileri, Konya.

Birdir, K. ve Akgöl, Y. (2015). Gastronomi turizmi ve Türkiye'yi ziyaret eden yabanc1 turistlerin gastronomi deneyimlerinin değerlendirilmesi. Işsletme ve Íktisat Çalışmalar Dergisi, 3 (2), 57-68

Çevik, K.N. (1997).Türk mutfağının, Akdeniz mutfak kültürünün genel özellikleri yönünden değerlendirilmesinin önemi. 5. Milletlerarası Türk Halk Kültürü Kongresi Maddi Kültür Seksiyon Bildirileri, Ankara.: Kültür Bakanlığı Hagem Yayınları,

Doğdubay, M. ve Giritlioğlu. İ. (2008). Mutfak turizmi. Cevdet Avcıkurt ve Necdet Hacioğlu (Ed.), Turistik Ürün Çeşitlendirmesi (s.433-456) Ankara: Nobel Yayınevi.

Ertaş Y. ve M. Gezmen-Karadağ: (2013). Sağlıklı beslenmede Türk mutfak kültürünün yeri. Gümüşhane Üniversitesi Sağllk Bilimleri Dergisi, 2(1), 117-136

Erdek, F. (2011). Yiyecek içecek işletmelerinin pazarlama faaliyetlerinde yöresel mutfağın kullanımı. (Yayımlanmamış yüksek lisans tezi). Trakya Üniversitesi Sosyal Bilimler Enstitüsü

Karasar, N. (2014). Bilimsel araştırma yöntemleri. Ankara: Nobel Yayın Dağıtım. 
Merriam, S. B. (2013). Nitel araştırma desen ve uygulama için bir rehber. (S, Turan, Çev.). Ankara: Nobel Akademik Yayıncılık.

Özdemir, B. (2010) Dışarıda yemek yeme olgusu: kuramsal bir model Önerisi, Anatolia: Turizm Araştırmaları Dergisi, 21 (22), 218-232.

Ozguneş, R. ve Bozok, D. (2017). Gözde Bir Destinasyon Mutfăğ: Bodrum'un Yöresel Lezzetleri (ss.259-372). Gastronomi Üzerine Araştırmalar. Ankara: Detay

Samanc1 Ö.(2008). Imparatorluğun son döneminde İstanbul ve Osmanlı saray mutfak kültürü, İçinde: Arif Bilgin ve Özge Samanc1, Türk Mutfăğ. Ankara: T.C. Kültür ve Turizm Bakanlığ Yayınları.

Selwood, John (2003) Thelure of food: food as an attraction in destination marketing in manitoba, Canada, Michael Hall (Ed), Food Tourism Around the World: Management of Development and Markets (ss.178- 180) Great Britain: Elseiver

Sezer, Ş. (2006). İstanbul'un Unutulan Lezzetleri, Yemek ve Kültür, Çiya Yayınları, İstanbul.
Shahrim Ab. Karım, (2006) Culinary tourismas a destinationattraction: an empirical examination of the destination's food image and information sources. (Doctorate Dissertation). Oklahoma State University, USA.

Smith, A. Hall,C,M.(2003). Restaurants and local food in New Zealand. Hall, C, M. (Ed). Food Tourism Around the World: Management of Development and Markets. ss. 249-267. Great Britain. ISBN 0750655038.

Soriano, D. R. (2002). Customer'sexpectations factors in restaurants. The Situation in Spain. International Journal of Quality \& Reliability Management, 19 (8-9), 1055-1067. doi.org/10.1108/02656710210438122

Talas, M. (2005). Tarihi süreçte Türk beslenme kültürü ve Mehmet Eröz'e göre Türk yemekleri. Selçuk Üniversitesi Türkiyat Araştırmaları Dergisi, (18),273-283.

Tezcan M. (2008). Yemeklerin toplumsal fonksiyonları.Türk Mutfak Kültürü Üzerine Araştırmalar. Ankara: Türk Halk Kültürünü Araştırma ve Tanıtma Vakfı Yayınları 